\title{
Küreselleşme Çağında Bir Yumuşak Güç Unsuru Olarak Sağlık Diplomasisi
}

\section{Health Diplomacy as a Soft Power's Element in the Age of Globalization}

\author{
Orhan BATTIR ${ }^{\mathrm{a}^{*}}$ \\ ${ }^{a}$ Dr. Öğr. Üyesi, Karamanoğlu Mehmetbey Üniversitesi, İ̈BF Siyaset Bilimi ve Uluslararası İlişkiler Bölümü, 70200, Karaman/Türkiye. \\ ORCID: 0000-0002-6856-8351
}

\section{MAKALE BILLGISİ}

\section{Makale Geçmişi:}

Başvuru tarihi: 10 Nisan 2019

Düzeltme tarihi: 02 Mayıs 2019

Kabul tarihi: 10 Mays 2019

\section{Anahtar Kelimeler:}

Medikal Diplomasi

Sağlık Diplomasisi

Yeni Diplomasi

Yumuşak Güç

\section{ARTICLE INFO}

\section{Article history:}

Received 10 April 2019

Received in revised form 02 May 2019

Accepted 10 May 2019

\section{Keywords:}

Medical Diplomacy

Health Diplomacy

New Diplomacy

Soft Power

\section{ÖZ}

Uluslararası ilişkilerin belirleyici unsuru güç ve en önemli aracı da diplomasidir. Küreselleşmeyle birlikte pekçok kavram gibi bu iki kavram da değişime uğramış, geleneksel anlam ve algılarının ötesinde yeni tanımlar ve uygulamalarla çerçeveleri genişlemiştir. Özellikle Soğuk Savaş sonrasında askeri ve ekonomik varlığa dayalı sert güç karşısında, özendirme ve cazibe oluşturmaya dayalı yumuşak güç uluslararası politikada giderek önem kazanmaya başlamıştır. Aynı şekilde geleneksel diplomasi uygulamalarının yanında yumuşak güce dayalı birtakım yeni diplomasi modellerinin hayata geçtiği görülmektedir. Küresel sağlık sorunlarının çözümünde uluslararası işbirliklerini içeren ve sınıraşan sağlık hizmetlerinin etkili bir uluslararası politika aracı olarak kullanılmasına dayanan sağlık diplomasisi de bunlardan biridir. Bu çalışmada popülaritesi ve etkinliği giderek artan sağlık diplomasisinin uygulanma biçimleri, araçları, etkileşim düzeyleri ve aktörleri ele alınarak, gerçek bir dış politika aracı olup olmadığı üzerinde durulmaktadır.

\begin{abstract}
A B S T R A C T
The decisive element of international relations is power and the it's most important instrument is diplomacy. These two concepts, like many concepts with globalization, have changed considerably and their frameworks have expanded with some new definitions and practices beyond their traditional meanings and perceptions. Especially in the post-Cold War period, the soft power based on the incentive and attraction against the hard power based on the military and economic existence in the traditional sense has begun to gain importance in the international politics. Similarly, a number of new diplomacy models based on soft power have been implemented in addition to traditional diplomacy practices. Health diplomacy, which includes international cooperation in the solution of global health problems and based on the use of transboundary health services as an effective international policy instrument, is one of them. In this study, it is emphasized whether there is a real foreign policy instrument by taking into consideration the forms, tools, interaction levels and actors of health diplomacy, whose popularity and effectiveness is increasing.
\end{abstract}

\section{Giriș}

Tarihsel süreçte bireylerin, insan gruplarının, toplumların ve nihayet devletlerin birbirleriyle ilişkilerinde temel belirleyici unsur -niteliği ve kullanım şekli bağlamına göre değişiklik arz etse de- tartışmasız "güç" olmuştur. Yine ilkel toplumlardan günümüze kadar karşılıklı ilişkilerin değişmeyen ve önemini hiçbir zaman yitirmeyen aracı ise diplomasi olagelmiştir. Güç ve diplomasi olguları uluslararası ilişkilerin seyri ve işleyişi bağlamında birbirleriyle yakından ilgilidir. Uluslararası politikada devletlerin sahip olduğu gücün düzeyi, diplomasi alanında kabul görmelerinde ve başarılı sonuçlar elde etmelerinde en önemli etkendir denebilir. Aynı şekilde diplomasi kabiliyetinin yüksek olmasının da -gücün yıpratıcı ve reaksiyon doğurucu etkilerinin bertaraf edilerek- yapıcı yönü sayesinde olumlu sonuç almayı kolaylaştırıcı rol oynadığı şüphesizdir.

Her iki kavrama dair algıların ve dolayısıyla da tanımların zaman içerisinde değiştiği ve ilgilerini koruyarak dönüştüğü görülmektedir. Güç ve diplomasi kavramlarıyla ilgili algıların ve tanımların değişmesinden kasıt temelde bu kavramların niteliklerinin, düzeylerinin, araçlarının ve

\footnotetext{
* Sorumlu yazar/Corresponding author e-posta: obattir@kmu.edu.tr
} 
aktörlerinin uluslararası sistemin ișleyișine paralel olarak dönüşmesi ve yenilenmesidir. Küreselleşmeyle birlikte bu değişimin daha hızlı ve belirgin seyrettiğini söylemek mümkündür. Geride bıraktığımız birkaç on yıllık dönemde hayatın hemen her alanında çok yönlü etkileriyle gözlenebilen ve giderek hız kazanan ekonomik, sosyal ve politik küreselleşme sayesinde ulusal sınırlar ve mesafeler önemini yitirmiştir. Gelişen teknoloji ve iletişim/ulaşım imkanları sayesinde artık insanların, ürünlerin, paranın, bilginin, silahların, hastalıkların ve insan hayatına dair sayamadığımız -olumlu ya da olumsuz- pek çok şeyin dünya üzerinde dolaşımı insanlık tarihinde hiç olmadığı kadar hızlı ve kolay gerçekleşir olmuştur. $\mathrm{Bu}$ süreçte uluslararası sistemin işleyişinde hâkim olan ilişki biçimleri yanında, sisteme yön veren araçlar ve aktörler de değişmekte ve çeşitlenmektedir.

Günümüz küresel bilgi toplumunda gücün toprak, askeri güç ve doğal kaynaklardan ziyade bilgi, teknoloji ve kurumsal esnekliğe dayandığı görülmektedir (Wenger, 2001: 6). Devletlerin gücünden bahsedildiğinde artık sadece askeri ve ekonomik varlık düzeyleri ile baskı ve yaptırım kapasitelerini içeren sert güç (hard power) değil, aynı zamanda özendirme ve cazibe oluşturma ile karakterize yumuşak güç (soft power) unsurları da kastedilmektedir. ${ }^{1}$ Aynı şekilde diplomasi denildiğinde de sadece devletlerin resmi görevlileri (diplomatlar) eliyle yürütülen geleneksel ve formel ilişkiler değil, bunun yanında, daha çok yumuşak gücü çağrıştıran ve birtakım sivil aktörlerin de devrede olduğu; kültürel diplomasi, kamu diplomasisi, insani diplomasi, sağlık diplomasisi gibi yeni uygulamalar ve ilişki biçimleri de anlaşılmaktadır. Ancak her ne kadar kavramların anlamçerçeveleri genişleyip değişse de aralarındaki yapısal ilişki ve etkileşim varlığını sürdürmektedir. Uluslararası politika aktörlerinin sahip olduğu gücün kaynağının salt askeri ve ekonomik kapasiteye dayalı geleneksel unsurlardan yüksek katma değerli bilimsel/teknolojik gelişmelere ve sosyopolitik dinamiklere dönüşmesi, yeni diplomasi modellerinin ve süreçlerinin ortaya çıkmasına yol açmaktadır. Aynı şekilde diplomasi pratiklerinde görülen yeni gelişmelerin de gücün kavramsal çerçevesinin ve kullanım tercihlerinin belirlenmesinde etkili olduğu söylenebilir.

$\mathrm{Bu}$ çalışmada geleneksel algılara nazaran görece yeni sayllabilecek "yumuşak güç" ve yeni diplomasi uygulamalarından olan "sağlık diplomasisi" kavramları, aralarındaki ilişki bağlamında, teorik çerçevede ele alınacaktır. Sağlık diplomasisinin ne olduğu ve neleri içerdiği yanında, gerçek bir dıș politika aracı olup olmadığı da yer yer sorgulanacaktır. Sınıraşan sağlık hizmetleri konusunda bölgesel ve küresel düzeyde görülen aktivizm; bileşenleri, araçları, aktörleri, paydaşları ve pratikleri düzleminde -ayrintılı istatistiklere, tekil ülke uygulamalarına ve sayısal verilere değinmedenincelenecek, söz konusu politika ve uygulamaların sürdürülebilirliği yanında taraflara gerçek fayda sağlayıp sağlamadığı üzerinde değerlendirmelere yer verilecektir.

${ }^{1}$ Uluslararası politikada güç ilişkilerini açıklamada popüler ve önemli bir kavram olan yumuşak güç (soft power) -ve beraberinde sert güç (hard power) tanımlaması- ilk olarak 1990 yılında Joseph S. Nye tarafindan Bound to Lead: The Changing Nature of American Power ( New York, 1990) adlı kitabında kullanılmıştır (Nye, 2004: XI).

\section{Kavramsal ve Kuramsal Çerçeve}

Doğası gereği dinamik bir yapıya sahip olan siyaset biliminde üzerinde çalışılan konu ile ilgili kuramsal çerçevenin oluşturulabilmesi için; o konu hakkında bazı temel kavramların tanımlanarak ne olduğu ya da ne olmadığının ortaya konması adına, karşılaştırmalı anlam çerçevelerinin belirlenmesi önemlidir. Özellikle yeni bazı kavramlar, literatürde genel kabul görmüş, yerleşik kimi kavramlarla karıştırılabilmektedir. Bu nedenle zihinlerde birbirine yakın anlamlar çağrıştıran benzer kavramlar arasındaki farklılıklar ve farklı kavramlar arasındaki benzerlikler birlikte ele alınarak, anlam ilişkilerinin ve ayrışan yönlerinin ortaya konması gerekmektedir. $\mathrm{Bu}$ bölümde, çalışmanın ana konusunu belirleyen; yumuşak güç, diplomasi ve sağlık diplomasisi kavramları, çerçeveleri çizilerek tanımlanacak ve bunlarla anlam ilişkisi olduğu düşünülen bazı kavramlar da açıklanmaya çalışılacaktır.

\subsection{Uluslararası politikada Güç, Sert Güç, Yumuşak Güç Kavramları Üzerine}

Anlam çerçevesi tam olarak belirlenmiş ve tanımı üzerinde net bir uzlaşı sağlanmış olmasa da "güç", uluslararası politika analizlerinde en çok başvurulan ve belirleyici rolüne vurgu yapılan temel kavramların başında yer almaya devam etmektedir. Özellikle II. Dünya Savaşı ve sonrasında dünya genelinde ortaya çıkan siyasi tablo ve değişen tehdit algıları ile birlikte devletlerin güce ve güç unsurlarına sahip olmaya atfettikleri önemin giderek arttığı görülmektedir. Soğuk Savaş yıllarının sonuna kadar uluslararası ilişkiler alanında hâkim paradigma olan realist bakış açısı ile değerlendirildiğinde, uluslararası ilişskilerin temelinde kendi ulusal çıkarlarını maksimize etmeye çalışan devletler arasındaki güç mücadelesi yer almaktadır (Baylis ve Smith, 2005: 273). Buna göre uluslararası politika özünde bir güç savaşıdır ve nihai amacı ne olursa olsun öncelikli hedef daima güce sahip olmaktır (Morgenthau, 1948: 13). Realist paradigmaya göre güç; A'nın B üzerinde, B'nin kendi istek ve iradesiyle yapmayacağı şeyi B'ye yaptırabilme kabiliyeti (Dahl, 1957: 202-203) ya da bir ülkenin, elindeki olanak ve yetenekleri ödül, ceza, ikna ve zorlama gibi çeşitli stratejiler yoluyla kullanarak karşı tarafın davranışlarını kendi çıkarları doğrultusunda etkileme ve yönlendirme kapasitesidir (Holsti, 1964: 179). En genel ifadesiyle güç; bir devletin diğer bir devlete uyguladığı ve normal şartlarda kendi iradesiyle yapmak istemeyeceği bir şeyi yapmasını sağlamaya yönelik etkidir (Ar1, 2013: 136).Devletler düzeyinde bu etkiyi ve kapasiteyi belirleyen unsurlar ise kuşkusuz askeri ve ekonomik parametreler olmaktadır. Devletlerin elde etmek istediği, yaptırıma ve zorlamaya dayalı olan, niteliği itibarıyla "sert" güç esasen bir amaç değil, ulusal çıkarların gözetilmesinde ve ulusal güvenliğin sağlanmasında bir araçtır (Waltz, 1990: 35). Ancak uluslararası sistemde güce atfedilen önemin, çoğu zaman, güç unsurlarına daha fazla sahip olmanın devletlerin asli hedefi gibi algılanmasına yol açtığı ve küresel rekabetin de bu yönde şekillendiği görülmektedir.

Uluslararası politikada sert güç kavramı; devlet düzeyinde bir aktörün ekonomik ve askeri olanaklarını yaptırım aracı olarak kullanarak başka aktör veya aktörlerin davranışları üzerinde kendi lehine değişiklik yapabilme veya nüfuz sağlayabilme becerisine karşılık gelmektedir. Teorik düzeyde sert gücün karşısında konumlandırılan yumuşak 
güç ise; bir ülkenin/devletin dünya siyasetinde elde etmek isteği sonuçlara, onun değerlerine hayran olan, onu örnek alan, refah düzeyine ve firsatlarına özenen diğer ülkelerin/devletlerin kendisini izlemesiyle ulaşması durumunu ifade etmektedir (Nye, 2005: 14-15). Somut kaynakların kontrolü yoluyla elde edilen sert güç, başkalarının davranışlarını şekillendirmeye yararken, yumuşak gücün işlevi ise başkalarının davranışlarından önce tercih ve isteklerini şekillendirme yeteneğidir (Nye, 1990: 166-168). Sert güç daha çok askeri ve ekonomik kaynakların ya da siyasi ilişkilerin ve ülkelerin diasporaları tarafından yürütülen lobi faaliyetlerinin doğrudan veya dolaylı "yaptırım aracı" olarak kullanılması ile karakterizedir. Buna karşılık yumuşak güçte ise aynı kaynaklar ve ilişkiler yanında; inançlar, değerler, fikirler, teoriler, söylemler, eğitim, kültür, hayat tarzı, gelenekler ve ülkenin imajı gibi unsurların "özendirme ve cazibe oluşturma aracı" olarak kullanılması yönündeki stratejiler ve süreçler belirleyici olmaktadır.

Temelde devletlerin sahip olduğu askeri ve ekonomik kapasiteye bağlı olan sert gücün kullanımında tercih edilen araçlar genellikle karşıdakine baskı kurma, yaptırım uygulama, ödemelerde bulunma, rüşvet vb. iken, davranış kalıpları da emretme, zorlama, ikna etme, korkutma, caydırma şeklindedir. Ancak küreselleşmeyle birlikte ekonomik ilişkilerin ön plana çıkması, askeri güç ve yaptırım endeksli resmi ilişkilerin ağırlığını kaybetmesine, onların yerine ekonomik unsurların ve devlet dışı aktörlerin devreye girmesine yol açmıştır (Nye, 1990: 156-157). Yeni araç ve aktörlerin devreye girmesiyle gündeme gelen yumuşak güç kullanımında etkileşim çerçevesi olarak, gündem yaratma, cazibe oluşturma ve yanına çekme gibi yöntemler ön plandadır. $\mathrm{Bu}$ yöntemlerin uygulanması sürecinde yumuşak gücün başlıca kaynakları arasında kurumlar, değerler, kültür ve politikalar yer almaktadır (Çavuş, 2012: 24-25).

Uluslararası politikada sert güç kullanımı daha çok, devletlerin fiziki varlığına ilişkin göstergeleri durumundaki coğrafya, nüfus, ekonomik kapasite, askeri kapasite, teknoloji ve doğal kaynaklar gibi gücün, belli yöntemlerle ölçülebilen, sayılabilen, karşılaştırılabilen nicel unsurlarıyla ilgilidir. Yumuşak güç kullanımını ise sayısal verilerle ve konvansiyonel ölçme yöntemleriyle ifade edilemeyen ancak etkisi kabul edilip açıklanabilen nitel unsurları durumundaki; hükûmetin niteliği, yönetim şekli, diplomasi kültürü, tarih, kimlik, kültür, din, ideoloji, milliyetçilik, ulusal moral gibi nitel unsurlarla açıklamak mümkündür (Ateş, 2013: 165-168). Ancak her ne kadar yöntemleri, araçları ve aktörleri birbirinden farklı olsa da sert güç ve yumuşak güç, başkalarının davranışlarını etkileyerek kendi amaçlarını gerçekleştirmeye yönelik politika ve uygulamaların iki farklı seçeneği olarak karşımıza çıkmaktadır.

\subsection{Diplomasi}

Devletlerin dış politikaya dair konularda diğer devletlerle yürüttüğü, çoğunlukla müzakereye dayalı ilişkilerin genel ifadesi olarak kavramsallaşan diplomasi; uluslararası ilişkilerin karşılıklı olası zararların önlenmesi adına savaş yolu ile değil barışçıl yol ve yöntemlerle yürütülmesi (Dağ, 2004: 146), devlet yönetiminde diş ilişkilerin, diş politikanın yürütülmesi ile ilgili tüm kaide ve kurallar (Kürkçüoğlu, 2005: 312) ya da hükûmetlerin dış ilişkilere dair tercih ettiği politikalarının ve görüşlerinin resmi mekanizmalar aracılığıyla diğer devletlerin karar vericilerine iletilmesi süreci (Gönlübol,1993: 116) gibi farklı pek çok şekilde tanımlanabilir.

Diplomasinin anlam çerçevesini belirleyici nitelikte üç unsurdan söz etmek mümkündür. Birincisi diplomasinin devletler arasinda cereyan etmesi ve siyasi, askeri, ekonomik, kültürel ilişkiler başta olmak üzere her türden etkileşime dair olmasıdır. Íkincisi şiddet ve zorlama unsurlarının olmadığı, görüşme, müzakere ve anlaşmalara dayalı barışçıl yollarla yürütülmesidir. Üçüncüsü de doğrudan devletin tüzel kişiliğini temsil eden, onun adına belli esaslar ve sınırlar içerisinde konuşmaya ve davranmaya ehil resmi görevliler eliyle yürütülme özelliğidir. Diplomasi, tarafların/devletlerin birbirlerini tanıması, diplomatik dokunulmazlık ilişkileri, profesyoneller eliyle yürütülmesi, kendine özgü bir kültürü olması ve günümüzde kalıcı misyonlara sahip olması yönüyle uluslararası politikanın en yerleşik kurumlarından biri durumundadır (Ateş, 2013: 387-388). Birbirinden farklı çok sayıda tanımı yapılabilir olsa da diplomasinin, özünde sorunların savaş dışı seçeneklerle çözülmesine yönelik çabaları içerdiğine dair alg1 pek değişmemektedir. Bu yönüyle uluslararası aktör temsilcileri arasında resmi düzeyde yürütülen görüşmeler bütünü olarak kabul edilen diplomasi, barışın korunmasına hizmet eden, bir kriz söz konusu olduğunda ise sorunun giderilmesinde tehdit ve güç kullanımından önce başvurulan araçların başında gelmektedir (Yılmaz, 2007: 42).Uluslararası politikada savaş dişındaki en uygun seçeneklerin belirlenmesine dayanan ve taraflar açısından risklerin, dolaylı-dolaysız tüm maliyetlerin minimize edilmesine imkân sağlayan diplomasi, zor kullanma ve yaptırımlardan ziyade yapıcı yönüyle kolay sonuç almaya elverişlidir. $\mathrm{Bu}$ yönüyle diplomasiyi meşruiyet düzeyi en yüksek dış politika aracı olarak nitelendirmek yanlış olmaz.

Diplomasi faaliyetlerinin, yetkili ve ehil durumdaki resmi görevliler tarafından, devletlerin dış politika hedefleri ve hassasiyetleri doğrultusunda, uluslararası toplumun aktörlerince benimsenen ve tarafları bağlayıcı nitelikte olan hukuki normlar çerçevesinde yürütülmesi esastır. Uluslararası politikada formel düzeyde diplomatik ilişkiler halihazırda büyük ölçüde 18 Nisan 1961 tarihli Diplomatik İlişkiler Hakkında Viyana Sözleşmesi'nde belirlenen usul ve esaslar çerçevesinde, yine bu sözleşmede tanımlanan resmi görevliler tarafından yürütülmektedir. ${ }^{2}$ Ancak uluslararası sistem dinamiktir ve küreselleşmeyle birlikte günümüzde insan hayatına dair hemen her alanda yaşanan kaçınılmaz değişim ve dönüşümlerden muaf değildir. Bu yönüyle sistemin işleyişinde yaşanan hızlı değişim ve dönüşüm uluslararası politika tercih ve uygulamalarında yeni bazı araçların ve aktörlerin devreye girmesi sonucunu beraberinde getirmiştir. $\mathrm{Bu}$ süreçte geleneksel anlamda diplomatlar eliyle yürütülen dış politika pratiklerinden, yöntem, uygulayıcılar, paydaşlar ve araçlar açısından, işleyişinde ve icrasında önemli farklılıkları bünyesinde barındıran; kamu diplomasisi, kültürel diplomasi, insani

\footnotetext{
${ }^{2}$ Bkz. 18 Nisan 1961 tarihli Diplomatik İlişkiler Hakkında Viyana Sözleşmesi,

(Erişim:23.01.2019)http://www.unicankara.org.tr/doc_pdf/Diplom atik_Iliskiler_1961.pdf
} 
diplomasi, dijital diplomasi, sağlık diplomasisi gibi yeni ilişki biçimlerinin/diplomasi modellerinin gündeme geldiği görülmektedir. Resmi anlamda "diplomat" olmayan görevlilerce yürütülen bu tür ilişki biçimleri alternatif iletişim ve etki kanalları açmak suretiyle devletlerin diplomatik süreçlerini desteklemektedir (Erman, 2016: 78). Formel diplomasi süreçlerinden farklı işleyen bu uygulamaların gayr-1 resmi diplomasi ya da sivil diplomasi şeklinde tanımlanması mümkündür.

\subsubsection{Diplomasi Anlayışındaki Dönüşüm}

Buraya kadar yapılan tanımlara ve çizilen kavramsal çerçeveye bakıldığında uluslararası ilişkilerin temel unsurunun -tüm versiyonlarıyla- "güç" ve birincil aracının da -eski ve yeni tüm modelleriyle- "diplomasi” olduğu ve bu iki olgu arasında esasen sıkı bir bağın bulunduğu söylenebilir. Yine yukarıda yer verilen açıklamalar ışı̆̆ında her iki kavramın, kısmen bağımsız kısmen de birbiriyle ilintili olarak, zaman içerisinde değişip dönüştüğü ve yeni formlara büründüğü görülmektedir. Gerek uluslararası sistemde güce dair algılarda görülen değişimin gerekse buna bağlı olarak gündeme gelen yeni diplomasi yaklaşımlarının küreselleşme süreciyle yakından ilgili olduğunu ve Soğuk Savaşın sona ermesiyle birlikte hem teorik düzeyde hem de uluslararası politika pratiklerinde daha fazla görünürlük kazandığını söylemek mümkündür.

Küreselleşme hem kavramsal hem de reelpolitik düzlemde daha eski bir olgu olsa da özellikle Soğuk Savaş sonrası dönemde seyri hızlanmış ve uluslararası politika gündemleri başta olmak üzere hemen hemen tüm sosyal bilimlerin en popüler kavramları arasında yerini almıştır. Küreselleşmeyle birlikte gelişen ulaşım ve iletişim teknolojileri sayesinde bireylerden çok uluslu şirketlere, sivil toplum kuruluşlarından (STK'lar) devletlere ve uluslararası kuruluşlara kadar tüm aktörler arasında yoğun ve sıra dişı bir irtibatlanma söz konusudur. Uluslararası sistemin aktörleri arasındaki ilişkilerde küreselleşmenin etkileriyle- ön plana çıkması, devletler arası düzeyde ekonomik ve askeri ilişkilerin, toplumsal etkileşimin, iç ve dış politika gündemlerinin yoğunlaşmasını ve çeşitlenmesini beraberinde getirmiştir.

Küreselleşme ile birlikte politik, ekonomik, sosyal ve kültürel unsurların devletler/toplumlar arasında giderek artan geçişkenliğine bağlı olarak toplumlar birbirine daha yakın, daha bağımlı, aynı zamanda etkileşime daha açık hale gelmektedirler. Bu süreçte hızı, etkinliği, niteliği ve niceliği artan uluslararası etkileşim, devletlerin ve toplumların hemen her alanda, daha fazla irtibatlı olmasını, daha yoğun, yeni ve çok boyutlu ilişkiler kurmasını adeta zorunlu kılmaktadır. Söz konusu yeni ve çok boyutlu ilişkiler geleneksel yol ve yöntemlerden ziyade alana eklemlenen yeni araçlar ve aktörlerle yürütülmektedir. Bu yeni yapıda artık devletler uluslararası politika hedeflerine ulaşmak için, askeri ve ekonomik araçlarla yetinmemekte, daha çok yumuşak güç kullanımına dayalı yeni dış politika araçlarına yönelmektedir. Güç tercihlerinde görülen değişime paralel olarak, diş politikaya dair kavramların merkezinde yer alan diplomasi kavramı da bu süreçte önemli ölçüde değişikliğe uğramıştır.

Günümüz dünyasında değişen güç dengeleriyle beraber uluslararası politikanın işleyişi şekil değiştirmiş, geleneksel diplomasi uygulamaları büyük ölçüde yerini yeni diplomasi kanallarına bırakmıştır. $\mathrm{Bu}$ yeni diplomasi şekli, hükümetler/devletler arası formel iletişimin yanı sıra, hükümetlerin diğer ülkelerin kamuoylarıyla ve farklı ülkelerin kamuoylarının birbirleriyle kurduğu iletişim ve etkileşim biçimlerinden oluşmaktadır (Kalın, 2011: 11). Uluslararası politikanın inşa ve yürütülme tarzı olan diplomasi kavramı özellikle Soğuk Savaş sonrası dönemde klasik anlamının ötesinde daha geniş bir çerçevede algılanır olmuş ve buna bağlı olarak hem teorik düzeyde hem de küresel politika uygulamalarında yeni bazı diplomasi modelleri yaygın bir şekilde hayata geçirilmeye başlanmıştır. Geleneksel diplomasiden yöntemleri, güç tercihleri, araçları ve aktörleri yönünden ayrılan yeni diplomasi uygulamaları; gücün ve güç unsurlarının yaptırım ve zorlama aracı olarak kullanılmasından ziyade, devletlerin sahip oldukları maddi ve manevi değerlerin/imkanların diğer devletler nazarında birer cazibe unsuru olarak daha yumuşak, daha az maliyetli, uzun vadeli, yapıcı ve kalıcı sonuçlar almaya yönelik kullanılmasıyla karakterizedir. Diplomasi kavramının geleneksel yaklaşımlara nazaran çok daha kapsayıcı bir anlam kazanmaya başladığı bu süreçte, yeni araç ve aktörlerin devreye girmesiyle, farklı yaklaşım ve yöntemlerle icra edilen ve tanımlanarak kavramsal çerçevesi çizilmesi gereken uygulamalardan biri de sağlık diplomasisidir.

\section{Küreselleşme Çağında Sağlık Diplomasisi}

Bugüne kadar birbirinden çok farklı yorumlar ve tanımlarla değişik platformlarda hemen her düzeyde değerlendirmelere konu olan küreselleşmenin sosyolojik, politik, ekonomik, kültürel vb. pek çok özelliğinden ve uluslararası toplum üzerinde olumlu ya da olumsuz etkilerinden söz etmek mümkündür. Ancak küreselleşmenin en basit ve belki de en temel özelliği/etkisi dünya genelinde geleneksel sınırların ortadan kalkmasına ya da en azından önemini yitirmesine yol açmasıdır. Sınırlardan kasıt sadece ülkeler/devletler arasında çizilmiş siyasi sınırlar değil, insanların dünyanın neresinde olursa olsun birbirleriyle irtibatını, temasını engelleyen ya da zorlaştıran -fiziki veya manevi- her türden bariyerlerdir.

Toplumlar ve/veya devletler arasındaki ilişkilerin her dönemde farklı boyutlarda ve şekillerde de olsa mutlaka var olduğu, ancak zaman içerisinde bu ilişkilerin niteliğinin, yöntemlerinin ve aktörlerinin değiştiği tarihsel bir gerçekliktir. Küreselleşme çağında özellikle bilgi, iletişim ve ulaşım teknolojileri başta olmak üzere hemen her alanda yaşanan gelişmelere bağlı olarak söz konusu değişim çok daha hılı seyretmektedir. Küreselleşme sürecinde sınırların fiilen önemini yitirmesiyle birlikte; aralarındaki coğrafi yakınlık ya da uzaklıktan bağımsız olarak, toplumlar, devletler ve hatta kitalar arasında insanların, bilginin, paranın, ticaret mallarının, silahların, hastalıkların, kısacası insan hayatını olumlu ya da olumsuz etkileyen hemen her şeyin, tarihte hiç olmadığı kadar hızlı ve kolay bir şekilde dolaşabilir hale gelmesi yine bu çağın/dönemin en önemli özelliklerindendir.

Gelişen iletişim ve ulaşım araçları sayesinde gerek turistik amaçla gerekse ticaret, eğitim, çalışma, yeni bir yaşam kurma hedefi gibi çok farklı nedenlerle insanların farklı ülkeler/bölgeler arasında dolaşımı sürekli bir artış içerisindendir. Tüm bunlara politik, ekonomik, güvenlik vb. gerekçelerle giderek büyüyen ve devletler açısından önemli 
bir sorun haline gelen, iradi ya da zorunlu göç niteliğinde bireysel ve/veya kitlesel insan hareketliliğinin de eklenmesiyle birlikte uluslararası toplumun ve küresel politika aktörlerinin kayıtsız kalamayacağı bir tablo ortaya çıkmıştır. Bu yeni ve dinamik yapıda ekonomiden eğitime, güvenlikten gıdaya ve sağlığa kadar pek çok alanda küresel düzeyde yaşanan gelişmeler devletlerin ya da toplumların "kendi" sorunları olmaktan çıkıp tüm insanların/insanlığın sorunları haline gelmiştir. Küresel sağlık sorunları denildiğinde genellikle ilk olarak bulaşıcı/salgın hastalıklar ile aşlama, ilaçlar, tedavi yöntem ve gereçleri gibi konularda uluslararası iş birliğini zorunlu kılan hastalıklar/durumlar akla gelmektedir. Ancak dünyanın herhangi bir bölgesinde yaşanan savaşlar, iç savaşlar ya da aşırı yoksulluk, kuraklık, doğal afetler gibi insani kriz durumlarında da yine uluslararası iș birliğiyle sağlanabilecek hızlı ve etkili sağlık yardımlarına ihtiyaç duyulabilmektedir. Bu anlamda -küresel- sağlık sorunları ve aynı zamanda bu sorunlarla mücadele süreçleri devletlerin ve devlet üstü yapıların en önemli ortak çalışma alanlarından biridir denebilir.

Uluslararası politika aktörleri tarafından, küresel düzeyde doğrudan ya da dolaylı olarak etkili olan (bazen küresel tehdide dönüşebilen) sağlı sorunlarıyla mücadele konusunda, iş birlikleri yoluyla gerçekleştirilen her türlü girişimin sağlık diplomasisi çerçevesinde değerlendirilmesi mümkündür. Sağlık diplomasisi pratikte çok daha eski dönemlere dayanıyor ve farklı şekillerde fiilen uygulanıyor olsa da kavram ilk olarak 1978'de, ABD başkanı Jimmy Carter'ın yardımcısı/sağlık danışmanı olan Peter Bourne tarafından gündeme getirilmiştir. $O$ dönemde sağlık hizmetlerinin uluslararası ilişkilerin geliştirilmesindeki öneminin ABD tarafından tam kavranamadığını savunan Bourne; sağlık başta olmak üzere belli başlı insani konuların diyalog kurma ve diplomatik engelleri aşmada önemli bir araç olabileceğini ifade etmiștir (Bourne, 1978: 121). Devam eden birkaç on yıllık süreçte sağlık diplomasisi kavramı hem akademik çevreler hem de politika yapıcılar tatarından bilinir ve kullanılır hale gelmiştir (Kickbush ve diğ., 2007: 971-973). Bu süreçte sağlık diplomasisi hükümetler, uluslararası kuruluşlar, özel sektör ve sivil aktörler tarafindan uluslararası ilişkilerin geliştirilmesi adına daha fazla benimsenir olmuştur (Drager ve Fidler, 2007: 162).

Sağlık diplomasisi, toplumun sağlığıyla ilgilenen ve siyasetle uğraşan paydaşlar arasında -karşılıklı- temsil ve iş birliğine dayalı olarak; anlaşmazlıkların çözümü, sağlık sistemlerinin iyileştirilmesi ve korunmasız topluluklar için sağlık hakkının güvence altına alınması için seçilen/tercih edilen etkileşim yöntemi olarak kabul edilmektedir (Health Diplomats, 2009). Özellikle yoksulluk ve istikrarsızlığın/çatışmaların hakim olduğu bölgelerde bir yandan uluslararası ilişkilerin iyileştirilmesi diğer yandan da küresel sağlığın geliştirilmesi gibi hedefleri içeren yeni bir alan (Adams ve diğ., 2008: 316) ya da etkileşim biçimi olan sağlık diplomasisi; yoksul ülkelerdeki insanların en çok ihtiyaç duydukları sağlık hizmetleri konusunda tıbbi bakım, sağlık personeli ve tecrübe ihraç ederek onların kalplerini ve akıllarını kazanmaya yönelik girişimler şeklinde de tanımlanabilir (Fauci, 2007: 1171). Küresel sağlık sorunlarıyla ilgili en güçlü ve etkin kuruluş olan Dünya Sağlık Örgütü'ne göre küresel sağlık diplomasisi; kamu sağlığı, uluslararası ilişkiler, yönetim, hukuk ve ekonomi gibi pek çok disiplini bir araya getiren, sağlık alanında küresel politikaları şekillendiren ve yöneten müzakerelere odaklanmakta, sağlık, dış politika ve ticaret arasındaki ilişkiyle şekillenmektedir. Sağlık diplomasisi; mevcut ve gelecekteki küresel sağlık sorunlarıyla mücadelede sistematik ve proaktif yaklaşımların desteklenmesi yanında, sağlık risklerinin azaltılması için üye ülkelerin kapasitelerinin geliştirilmesi ve ortak eylemlere destek verilmesi gibi çok yönlü majör hedefleri olan etkileşim süreçlerinin tamamıdır (WHO, t.y.).

Uluslararası iş birliğini gerekli kılan sağlık çalışmalarının, günümüz şartlarında esasen hukuki ya da siyasi bir sınırı yoktur. Koruyucu ve önleyici sağllk hizmetlerinden en ileri düzeyde tedavi yöntemlerinin kullanıldığı faaliyetlere kadar her türden sağlık hizmeti sunumu sağlık diplomasisinin konusu olabilmektedir. Bunun yanında sağlık teknolojilerinin geliştirilmesi, nitelikli sağlık profesyonellerinin yetiştirilmesi ve bunlar için gerekli yatırımların iş birliği içerisinde yapılması ya da topyekûn sağlık sistemi transferi/modellemesi gibi yapısal girişimler de önemli ve nitelikli sağlı diplomasisi uygulamalarındandır.

Özünde yumuşak güç eksenli bir etkileşim biçimi olan sağlık diplomasisi geleneksel diplomasi uygulamaları karşısında farklı süreçleri içeren yeni bir diplomasi modeli olarak konumlandırılabilir. Geleneksel diplomasinin temel hedefi, bilindiği üzere, tüm unsurlarıyla gücün ve ulusal çıkarların maksimize edilmesidir. Sağlık diplomasisi kapsamında gerçekleştirilen politika ve uygulamaların ise; güç ve ulusal çıkar hedefleri yanında, insan hayatı, insan hakları ve insan onuruyla ilgili evrensel değerlerin yükseltilmesi yoluyla etkileşim alanını genişletmek gibi dolaylı ancak etkili hedeflerinden söz etmek mümkündür.

Sağlık diplomasisinin taraflar açısından ekonomik, politik ya da ulusal güvenlikle ilgili bir etkileşim potansiyelinin bulunduğu ve pek çok farklı bileşeniyle bu alanda önemli bir boşluğu doldurduğu söylenebilir. Ancak doğrudan insan sağlığına ve insan hayatına ilişkin olması onu geleneksel diplomasi karşısında bir anlamda ayrıcalıklı kılmakta, böylece meşruiyet düzeyini yükseltmektedir. Bunun yanında alandaki aktörler ile kullanılan araçlar ve yöntemler de sağlık diplomasisinin meşruiyetini doğrudan etkileyen önemli unsurlardandır.

\subsection{Sağl1k Diplomasisinin Aktörleri}

Uluslararası politika ve onun birincil aracı durumundaki diplomasi temelde devletler arasında, nitelikli resmî görevliler eliyle yürütülen formel etkileşim süreçleridir. Kurumsal düzeyde devletler, bireysel düzeyde ise diplomatlar ya da tümüyle diplomatik misyon temsilcileri bu sürecin doğal ve birincil aktörleridir. Ancak bu durumun günümüz uluslararası sisteminde büyük ölçüde değiştiği, yeni, daha esnek ve dinamik aktörlerin devreye girmesiyle yeni etkileşim biçimlerinin ve rol paylaşımlarının gündeme geldiği görülmektedir. Yeni aktörlerin devreye girerek etkin roller üstlenmesi esasen uluslararası sistemde gücün, devletlerin tekelinden çıkarak yayılması ve belli ölçüde devlet dışı unsurlara geçmesi/kayması(power diffusion) (Nye, 2011: XV) anlamına gelmektedir. Uluslararası sistemde gücün devletlerden devlet dışı aktörlere kaymasını iki şekilde açıklamak mümkündür. Birincisi; belli ekonomik, politik, askeri vb. amaçlarla bir araya gelen 
devletlerden müteşekkil resmi nitelikli yapılar olan uluslararası örgütlerin güce ortak olmasıdır. Devletler bu örgütlerin asli unsuru olmakla birlikte doğrudan değil, dolaylı aktör konumundadır. Ikincisi; tamamıla resmi alanın dışında kalan sivil nitelikli aktörlerin nicelik ve nitelik bakımından gelișmesi, böylelikle devletleri/hükümetleri farklı yol ve yöntemlerle etkileyerek belli amaç ve hedefler doğrultusunda yönlendirebilecek etkinliğe ulaşması durumudur. Bu durumda sivil aktörlerin devletin yerine geçmeleri değil, devlet aracılığıyla dolaylı güç kullanmaları söz konusu olmaktadır (Battır, 2017: 6970).

Uluslararası sisteme birer güç unsuru olarak eklemlenen yeni aktörler ekonomiden güvenliğe, çevre sorunlarından insan haklarına kadar pek çok alanda olduğu gibi küresel sağlık politikaları ve sağlık diplomasisi konusunda da hükümetleri/devletleri belli ölçüde etkileme ve yönlendirme kapasitesine sahiptirler. Küresel sağlık sorunlarına küresel iş birlikleri yoluyla çözüm üretme süreçlerini içeren sağlik diplomasisi nitelikli, dinamik bir faaliyet alanıdır ve aynı şekilde nitelikli ve dinamik yeni aktörler eliyle yürütülmek durumundadır. Söz konusu yeni aktörler doğal olarak devlet dışı unsurlardır. Devlet dışı (non-state) ya da hükûmet dışı organizasyonlar (non-governmental organization/NGO) denildiğinde uluslararası sistemin devletler/hükümetler dışında kalan tüm aktörleri anlaşılabilir. Devlet dışı aktörler kuruluş biçimleri, statüleri, ölçekleri, amaçları, faaliyet konuları ve kâr amacı güdüp gütmemeleri gibi pek çok açıdan sınıflandırılabilir. Ancak aktörler/aktör grupları çok geniş bir yelpazede ele alındığında bazı ortak yanları ve kesişen özellikleri net bir ayrıma gitmeyi zorlaştırabilir. Bu nedenle sağlık diplomasisinin aktörleriyle ilgili olarak; resmi statüye sahip aktörler ve sivil aktörler şeklinde ikili, genel bir sınıflandırma daha açıklayıcı olabilir.

Resmi statüye sahip aktörler, devlet aygıtıyla organik bağı bulunan ya da devletlerin bir araya gelerek oluşturdukları formel yapılardır. Hükümetlerin sağlık bakanlıkları başta olmak üzere bünyesinde sağlık profesyonelleri bulunduran ve ülke sınırlarının dışında yabancı unsurlarla yatay ve/veya dikey etkileşim içerisinde bulunan, devlet yapısına dahil, her düzeyde kurum/kuruluş bu çerçevede değerlendirilebilir. Bunun yanında bölgesel ya da küresel düzeyde, devlet dışı ancak yine devletler tarafindan belli amaçlar etrafında kurulan, uluslararası alanda faaliyet gösteren, tarafları ve ilişki düzeyleri bakımından devletlerin merkezde olduğu örgütler de resmi nitelikli aktörlerdir. BM bünyesinde Dünya Sağlık Örgütü (WHO) gibi doğrudan, ya da Dünya Ticaret Örgütü (WTO), Gıda ve Tarım Örgütü (FAO), Uluslararası Çalışma Örgütü (ILO), Uluslararası Göç Örgütü (IOM), İnsani Yardım Koordinasyon Ofisi (OCHA), Birleşmiş Milletler Kalkınma Programı (UNDP), Birleşmiş Milletler Mülteciler Yüksek Komiserliği (UNHCR), Birleşmiş Milletler Çocuklara Yardım Fonu (UNICEF), BM Gönüllüleri (UNV), BM Kadın Birimi (UN Women) gibi dolaylı olarak küresel sağlık politikalarıyla ilgili çok sayıda kuruluşun bu kapsamda değerlendirilmesi mümkündür. Ancak uluslararası sağlık diplomasisi aktörlerinin BM bünyesindeki bu kuruluşlarla sınırlı olmadığını ifade etmek gerekir. Bunların dışında bölgesel nitelikte siyasi ve ekonomik birlikler de kendi bünyelerinde sağlık politikaları geliştirerek önemli projeleri hayata geçirebilmektedirler. Avrupa Birliği (AB) başta olmak üzere, Afrika Birliği Örgütü (Organization of African Unity - OAU), Arap Birliği (The League of Arab States), Şanghay İşbirliği Örgütü (Shanghai Cooperation Organization), Güney Doğu Asya Uluslar Birliği (Association of Southeast Asian Nations - ASEAN) gibi birliklerin de sağlık alanında -özellikle üye devletlerin sağlı sistemlerinin geliştirilmesine yönelik- faaliyetlerde bulunan uluslararası örgütler kategorisinde oldukları söylenebilir (Oral, 204: 8789). Aynı şekilde, gelişmiş ülkelerin ekonomik ve stratejik iş birliği çerçevesinde bir araya geldiği G-8 ve G-20 gibi oluşumlar da küresel sağlık sorunlarıyla mücadele konusunda önemli bir potansiyele sahiptir. Bu şekilde çok sayıda devletten müteşekkil uluslararası kuruluşların hem bölgesel hem de küresel sağlık sorunlarıyla ilgili faaliyetlerinin sağlı diplomasisi kapsamında değerlendirilmesi mümkündür. Bu arada küresel sistemdeki etki alanları ve işleyişleri bakımından tüm bu uluslararası kuruluşların/örgütlerin esasen hükûmetler arası yapılar olarak tanımlanmasının daha uygun bir yaklaşım olacağını ifade etmek gerekir (Ateş, 2012: 1; Sönmezoğlu, 2005: 54). Nitekim bu örgütlerin faaliyetleri, kararları ve uygulamaları genellikle kendi bünyelerindeki devletlerin/hükûmetlerin politikaları çerçevesinde gelişmekte ya da bu politikaları şekillendirmektedir.

Sivil aktörler, devletlerin ve devletler tarafından kurulan resmi nitelikli yapıların dışında kalan ve otoritenin kuşatıcı kontrolünden uzak olan sivil toplumun bünyesindeki tüm unsurları içermektedir. En geniş kapsamlı ve en sade ifadesiyle resmi otoritenin hâkimiyet alanı dışındaki ekonomik ve toplumsal alana karşılık gelen sivil toplumun örgütlü hali ve sosyopolitik yansıması ise sivil toplum kuruluşlarıdır (STK'lar). Amaçları ve fonksiyonları bağlamında, toplum yararını gözeten, gönüllülük esasına dayalı, kâr amacı gütmeyen STK'lar topluma hizmet etmeye ve siyaseti etkilemeye yönelik, resmi nitelikli olmayan, devlet/hükûmet dişı kuruluşlardır (Gönel, 1998: 1; Haştemoğlu, 2004: 35). Ulusal ya da küresel düzeyde siyasal sistemlerin işleyişinde rol alan sivil aktörlerden bahsedildiğinde genellikle, resmi otorite ile sivil alan arasındaki ilişkinin sağlıklı bir şekilde kurulmasında ve sürdürülmesinde önemli roller üstlenen vakıflar, dernekler, sendikalar, örgütlü çıkar grupları, mesleki birlikler gibi STK'lar akla gelmektedir. Bu tür STK'ların; özgürlükler, insan hakları, hukuk, adalet, sağlık, eğitim, çevre sorunları, gençlik, dezavantajlı gruplar, ekonomi, kalkınma, insani yardımlar gibi çok farklı alanlarda, kendilerine özgü yol ve yöntemlerle önemli çalışmalar yürüterek bireysel ve toplumsal hayatı şekillendirmede etkin roller üstlendikleri tartışmasızdır. Ancak bağımsızlık, özerklik, gönüllülük, rızaya dayalı katılım, yasalara uygunluk gibi nitelikleriyle STK'lar bu konuda çok önemli bir konuma sahip olsalar da alanın yegâne aktörü değildirler. STK'lar dışında uluslararası/çokuluslu şirketler, düşünce kuruluşları, sanat ve sporla ilgili popüler organizasyonlar (topluluklar, kulüpler vb.) ve bireyler de yerine göre ulusal veya küresel politika aktörü olabilmektedir. Bunlar içerisinde uluslararası şirketlerin ve bireylerin aktörlüğü doğrudan, diğerlerininki ise dolaylı aktörlük düzeyindedir. Ancak bireylerin genellikle tek başlarına değil, belli bir organizasyonun parçası olarak hareket etmeleri durumunda gerçek anlamda etkin bir aktör olabilecekleri unutulmamalidir. 
Küresel iş birliği gerektiren pek çok alanda olduğu gibi sağllk diplomasisinde de etkin roller üstlenen sivil aktörlerin devlet/hükûmet ile doğrudan organik bağları yoktur ve faaliyetlerini gerçekleştirirken devleti temsil etmezler. Ulusal ya da uluslararası nitelikte olan bu grup aktörler insan sağlığıyla ilgili konularda, sahip oldukları maddi ve beşeri kaynakları kullanarak doğrudan sahada olabildikleri gibi, dolaylı yoldan, kamuoyunu harekete geçirerek ya da hükûmetleri etkileyip yönlendirerek de sağlık diplomasisi yürütebilmektedirler. Doğrudan kendi öz kaynaklarıyla ya da resmi ve sivil diğer aktörlerle iş birliği içerisinde, uluslararası ölçekte düzenli ve devamlı faaliyetler gerçekleştirebilen yapılar sağlık diplomasisinin birincil düzey/asli sivil aktörleridir. Bu şekilde küresel sağlık sorunlarıyla doğrudan ya da insani yardımlar çerçevesinde dolaylı olarak ilgilenen ve herhangi bir ayrım gözetmeksizin dünyanın -ulaşabildikleri- her yerinde faaliyet gösteren çok sayıda sivil aktör bulunmaktadır. Uluslararası alanda etkinliği ve bilinirlik düzeyi yüksek olan; Uluslararası Kızılay- Kızılhaç Hareketi (International Red Cross and Red Crescent Movement), Sinır Tanımayan Doktorlar Örgütü (Médecins Sans Frontières - MSF), Dünya Tabipler Birliği (The World Medical Association), Yeryüzü Doktorları (YYD),Uluslararası Doktorlar Derneği (AID), Türk Kızılayı, İHH İnsani Yardım Vakfı gibi kuruluşlar bunlardan sadece bazılarıdır. Bunun yanında, ulusal düzeyde örgütlenmekle birlikte, temsil ettikleri ideolojiye, politik eğilimlerine, sahip oldukları ekonomik ve sosyal sermayeye dayanarak, sınıraşan sağlık sorunlarıla mücadele konusunda resmi otoriteyi yönlendirme kapasitesine sahip organizasyonları da ikincil düzey/tali aktörler olarak nitelendirmek mümkündür. Söz konusu sivil unsurların gerçek anlamda sağlık diplomasisi aktörü olup olmama durumları ve aktörlük dereceleri, küresel sağlık sorunlarının çözümüne yönelik bilfiil gerçekleştirdikleri faaliyetler yanında ulusal ve uluslararası düzeyde politika yapıcıları ve karar vericileri etkileme, ikna etme ve yönlendirme yetenekleriyle de ilgilidir.

Sağlık diplomasisinin sivil aktörlerinden kabul edilebilecek bir diğer unsur da sağlık hizmetleri sunumu ya da tedariki konusunda uluslararası faaliyetleri ve yatırımları olan özel sektör kuruluşlarıdır. Bu durumdaki özel girişimler temelde ekonomik saiklerle ve kâr amaçlı gerçekleşse de ülkeler ve toplumlar arasında tesis edecekleri güven ilişkisine ve oluşturdukları pozitif beklentiye dayalı olarak sağlık diplomasisi konusunda önemli roller üstlenebilmektedir. Ancak sağlık alanında bu şekilde gerçekleşen özel sektör yatırımlarının, uluslararası STK niteliğindeki vakıflar üzerinden yürütülen hizmetler ve yatırımlar yanında nicelik ve nitelik bakımında çok önemli bir yer işgal ettiğini söylemek zordur.

\subsection{Sağlık Diplomasisinde Araçlar, Yöntemler ve Etkileşim Düzeyleri}

Sağlık diplomasisinin yukarıda değinildiği şekilde geleneksel diplomasiden farklı aktörler tarafindan yürütülmesi -bu aktörlerin kapasite ve kabiliyetleriyle de doğru orantılı olarak- kullanılan yöntemlerin ve araçların da çeşitlenmesini beraberinde getirmektedir. $\mathrm{Bu}$ yöntem ve araçların en önemli özelliği, resmi ve sivil sağlık diplomasisi aktörlerinin farklı nitelikte paydaşlarla bazen yatay (denk statüde aktörler arasında) bazen de dikey (alt ya da üst statüde aktörlerle) etkileșimli iş birliği içerisinde hareket etmek zorunda olmalarıdır. Söz konusu iş birlikleri, tarafları açısından birkaç farklı şekilde kurulmakta ve buna göre adlandırılabilmektedir. Resmi ve sivil aktörler arasındaki ilişkiler temelde; i) devletler/hükümetler arasında (çekirdek diplomasi), ii) hükümetlerle diğer aktörler arasında (çok paydaşlı diplomasi), iii) hükümetlerin dışında kalan sivil aktörlerin birbirleriyle ve sağlık diplomasisi aktörü niteliğinde olmayan sivil unsurlarla etkileşimi (gayr-l resmi diplomasi) şeklinde gerçekleşebilmektedir (Katz ve diğ., 2011: 506). Bu durumda sağlık diplomasisinin yöntem ve araçları her bir aktör grubu/taraf açısından -hangisinin merkeze alındığına göre- farklı görünmekte ve farklı anlamlar ifade edebilmektedir. Bu çalışmanın belirleyici kavramlarından biri olan yumuşak gücün temelde devletlerin güç tercihleriyle ilgili olduğu düşünüldüğünde; sağlık diplomasisi yöntemlerinin ve taraflar arasındaki ilişki düzeylerinin devletlerin/hükümetlerin hareket tarzları açısından ele alınması yerinde olacaktır. $\mathrm{Bu}$ çerçevede hükümetlerin alandaki aktörlerle iş birliklerini ve farklı etkileşim süreçlerini; hükümetlerin uluslararası örgütlerle iş birliği,hükümetler arasında doğrudan temas ve sivil aktörlerin desteklenmesi şeklinde üç farklı düzeyde gözlemlemek mümkündür.

Hükümetlerin uluslararası örgütlerle iş birliği; dikey etkileşime dayalıdır ve yönetimler tarafından, sağlık diplomasisinin devletler dışındaki -yukarıda sayılan- resmi aktörleriyle birlikte hareket edilerek, küresel sağlık sorunlarının çözümüne katkı verilmesi şeklinde gerçekleştirilen uygulamalardır. Özellikle ekonomik ve sosyal gelişmişlik düzeyi düşük olan bölgelerde pek çok insani soruna da eşlik eden sağlık sorunlarının kısa, orta, uzun vadede çözümü ve kalıcı iyileştirilmesiyle ilgili faaliyetlerin tümü bu kapsamdadır. Söz konusu bölgelerde büyük hastalık yüklerinin, devletlerin kapasitelerinin zayıflamasına ve istikrarsızlaşmalarına yol açarak, bölgesel ve küresel tehditlere kapı aralaması yönünde duyulan endişeler küresel aktörleri çok yönlü koruyucu ve önleyici tedbirler almaya yönlendirmektedir. Hem bölgesel hem de küresel sağlık güvenliğini tesis etmek adına ortak hareket etme zorunluluğu yanında, tutarlı politikalar geliştirmek ve bunları hayata geçirmek için gerekli olan ekonomik ve beşerî kapasitenin büyüklüğü dikkate alındığında, bu tarz iş birliklerinin günümüz şartlarında kaçınılmaz olduğu açıktır.

Hükümetler arasında doğrudan temas; niteliği itibarıyla yatay ilişkiye dayalıdır ve teorik olarak denk statüler arası ilişki formundadır. Ancak devletlerin gelişmişlik düzeyi etkileşimin belirleyici unsurudur. Sağlık diplomasisi kapsamında değerlendirilebilecek bu düzeydeki ilişkiler genelde gelişmişten az gelişmişe doğru yardım ve destek faaliyetleri şeklinde görülür. Taraflar arasındaki gelişmişlik farkının çok fazla olması durumunda esasen fiilî bir dikey etkileşimin varlığından söz etmek de mümkündür. Bunun dışında hükümetler arası ilişkiler gelişmiş ülkelerin bölgesel ve/veya küresel sağlık sorunlarıyla mücadele ve sağlığın geliştirilmesi konusunda iş birlikleri şeklinde de gerçekleşebilmektedir.

Sivil aktörlerin desteklenmesi; hükümetlerin üstte olduğu dikey etkileşime dayalıdır ve iki şekilde görülebilir. Birincisi özel sektör girişimcilerinin desteklenmesidir. $\mathrm{Bu}$ destekleme daha çok sağlık alanında yurt dişında 
yatırımları/ortaklıkları bulunan özel sektör firmalarının ekonomik (birtakım imtiyazlar ya da muafiyetler yoluyla) ve bürokratik engelleri aşmalarını kolaylaştırma şeklinde olabilir. İkincisi STK'ların desteklenmesidir. Özellikle faaliyet konuları arasında farklı düzeylerde de olsa sağlık hizmetleri bulunan STK'ların yurtdışı faaliyetleriyle ilgili olarak hükümetler, çoğu zaman karş1lıklı iş birliği anlaşmaları yoluyla, kolaylaştırıcı uygulamalar gerçekleştirebilmektedir. Sağlık sorunlarının ve bu sorunlarla mücadele süreçlerinin doğrudan insan odaklı olması ve yaşama hakkı başta olmak üzere temel insan haklarına dayanması, alandaki STK'lar ve hükümetler arasındaki iş birliğini güçlendirmekte ve değerli k1lmaktadır.

STK'lar genelde faaliyetlerini resmi otoriteden bağımsız olarak, sivil nitelikli gerçekleştirme eğilimindedirler, ancak hükümetlerin desteğini almanın önemli birtakım avantajlarından da belli ölçüde yararlanmak durumundadırlar. Kendi ülke sınırlarının dışında gerçekleştirecekleri faaliyetleriyle ilgili diplomatik ve bürokratik süreçlerde tecrübe eksikliği, fiili kapasitelerinin yetersizliği ve kaynaklarının sınırlılığı nedeni ile STK'lar genellikle hükümetleriyle iş birliğine ihtiyaç duymaktadır. Ancak bu iş birliğinin karşılıklı kazanç temelinde gerçekleştiği göz ardı edilmemelidir. Devletlerin/hükümetlerin de yumuşak güç kullanımına dayalı bazı dış politika uygulamalarında başarılı olabilmek için STK'ların dinamik yapıları ile etkili bir şekilde yürüttükleri faaliyetlerinden yararlanma yoluna gittiği söylenebilir. Ayrıca hükümetler bir yandan sivil aktörleri desteklerken diğer yandan kaynakların etkin ve verimli kullanılması adına etkin bir koordinasyon rolü de üstlenmektedir. $\mathrm{Bu}$ anlamda hükümetlerin STK'ları ve diğer sivil diplomasi aktörlerini desteklemesi esasen resmi ve sivil kapasitelerin birlikte kullanılarak etkili sonuçlar elde edilmesi adına rasyonel bir yaklaşım olarak görülebilir.

Sayılan tüm bu etkileşim biçimlerinin, özünde, devletlerin muhatapları olan diğer devletler nazarında saygınlık kazanma ve bir cazibe unsuru olarak küresel imajına olumlu katkı sağlama hedefi/beklentisi içerdiğinde kuşku yoktur. Bu yönüyle sağlık diplomasisinin yumuşak güce dayanan, dolaylı, ancak gerçek bir dış politika aracı olduğunu söylemek mümkündür. Uluslararası sistemin işleyişiyle ilgili, küresel politika aktörleri arasında, geleneksel diplomatik ilişkiler yanında yeni bir diplomatik etkileşim modeli olan sağlık diplomasisinin sahadaki uygulamaları farklı düzeylerde, ancak çoğunlukla ardışık süreçler şeklinde gerçekleşmektedir.

\subsection{Sağlık Diplomasisinin Temel Dinamikleri ve Uygulama Düzeyleri}

Aktörleri, araçları ve hedefleriyle ilgili olarak yukarıda değinilen hususlardan ve yapılan tanımlardan yola çıkarak sağlık diplomasisi uygulamalarının; birincisi, küresel sağlık sorunlarına çözüm yolunda diplomasi yürütülmesi ve ikincisi, uluslararası ilişkilerin geliştirilmesi adına sağlık hizmetlerinin araçsallaştırılması şeklinde iki boyutundan söz edilebilir. Her iki boyutta da gerçekleştirilen faaliyetlerin yumuşak güç eksenli sivil diplomasi uygulamaları kapsamında değerlendirilmesi mümkündür. Dünya genelinde herhangi bir ülke ya da bölge ayrımına gitmeksizin sağlık sorunlarıyla mücadele ve toplumların sağlık düzeylerinin geliştirilmesi gibi küresel hedeflerle hareket edilmesi ve sonuçlarından tüm insanlığın belli ölçüde etkilenmesi yönüyle sağlık diplomasisinin; küresel kamusal değer üreten bir aktivizm içerdiğini ve hareket noktasının bu değeri büyüterek güvence altına almak olduğunu söylemek yanlış olmaz. Sağlık diplomasisi çerçevesinde değerlendirilebilecek faaliyetler nitelikleri yanında önem ve öncelikleri açısından da çok farklı sınıflandırmalarla ele alınabilir. Ancak resmi ve sivil sağlık diplomasisi aktörlerinin saha uygulamalarına bakılarak sistematik bir sinıflandırmaya gidildiğinde, söz konusu faaliyetlerin; acil/insani yardım faaliyetleri, tedavi edici hizmetler, koruyucu ve önleyici sağllk hizmetleri, fiziki ve beşerî kapasite geliştirme ve sistem transferi şeklinde ardışık beş ayrı düzeyde gerçekleştiği söylenebilir.

\subsubsection{Acil/Insani Yardım Faaliyetleri}

İnsan ya da doğa kaynaklı afetler, yoksulluk, kuraklık, salgın hastalıklar, iç çatışmalar, savaşlar ya da zorunlu kitlesel göç hareketleri gibi insani kriz niteliğindeki her türlü olumsuz durum karşısında devletler/hükümetler acil insani yardıma ihtiyaç duyabilmektedirler. Can güvenliği başta olmak üzere, kendi imkânlarıyla üstesinden gelemeyecekleri sorunlarla karşı karşıya kalan ve yardıma muhtaç durumda bulunan insanlara yönelik her türlü yardım bu kapsamdadır. Acil/insani yardımlar ilk planda -gerekli olduğu durumlarda- arama-kurtarma faaliyetleri ve ardından insanların hayatta kalmalarını sağlayarak, gıda, su ve ilaç temini, acil sağlık hizmeti, giyinme ve barınma gibi temel fizyolojik ihtiyaçların karşılanmasıyla ilgilidir. Bu anlamda insani yardım faaliyetleri ile sağlık diplomasisinin, içerik ve uygulama süreçleri bakımından iç içe olduğu söylenebilir. Yakın geçmişte ve günümüzde özellikle deprem, tsunami, sel baskınlar ya da aşırı kuraklık gibi doğal afetlerde bu tür acil yardım faaliyetlerinin çok sayıda örneği bulunmaktadır. Haiti depremi (2010), Endonezya (2004) ve Japonya'da (2011) yaşanan tsunami felaketleri, yakın dönemde Sudan ve Somali başta olmak üzere Sahra Altı Afrika ülkelerinde görülen aşırı kuraklık ve açlık sorunu karşısında resmi ve sivil uluslararası aktörler tarafından gerçekleştirilen çalışmalar bunlardan sadece bazılarıdır.

Acil insani yardım faaliyetleri kapsamında taraflar ilk kez temas etmişlerse bunun genellikle orta ve uzun vadede olumlu ilişkilerin kurulup geliştirilmesine vesile olması beklenir. Devletler arasında bu şekilde kurulan dostluk ilişkilerinde, doğrudan insan hayatını/sağlığını kurtarma ve korumaya yönelik yardım faaliyetlerinin önemi tartışmasızdır. Sağlık diplomasisi çerçevesinde değerlendirilebilecek acil insani yardımlar bazen de ilişkileri çok iyi olmayan, siyasi, askeri ya da ekonomik nedenlerle birtakım gerginlikler yaşayan devletler/hükümetler arsasında bir yumuşama aracı olabilmektedir. Barış zamanlarında ve doğrudan insan hayatıyla ilgili uluslararası acil insani yardım söz konusu olduğunda hükümetler ya da toplumlar arasındaki siyasi, ekonomik ya da askeri anlaşmazlıklar genellikle -geçici bir süreliğine de olsa- ötelenip göz ardı edilmekte ve normal şartlarda ön görülmeyen yakınlaşmalar ve temaslar gerçekleşebilmektedir. Bu şekilde gelişen bir etkileşimin, taraflar arasındaki gerginliği yok etme ya da azaltma konusunda geleneksel diplomasi yöntemlerinden çok daha 
etkili olduğunu ve olumlu sonuçlar doğurabileceğini söylemek mümkündür.

\subsubsection{Tedavi Edici Hizmetler}

Özellikle az gelişmiş ve yeterli düzeyde sağlık hizmetlerine erişim sorunu yaşayan bölgelerde/ülkelerde, yine insani yardımlar kapsamında, ancak acil yardımlardan farklı olarak, planlı organizasyonlar çerçevesinde gerçekleştirilen faaliyetlerdir. Doğrudan hükümetler ya da hükümetlerin onaylayıp destek verdiği sivil aktörler tarafından, ilk planda yardım alan tarafla birlikte belirlenen genellikle elverişsiz ya da geçici tesislerde yürütülse de bu aşamada verilen sağlık hizmetlerinin niteliği ve çeşitliliği belli ölçüde artmaktadır. Teşhis ve tedaviye yönelik sağlık hizmetleriyle, yerel şartlar ve imkanlarla çözümü mümkün gözükmeyen pek çok sağlık sorunu yardım yapan tarafın profesyonel ekiplerince ve genellikle herhangi bir ücret karşıllı̆ı olmaksızın çözülmektedir. Sahra Altı Afrika Ülkelerinde çok sık görülen katarakt hastalığının ameliyatla tedavi edilmesine yönelik, özellikle insani yardım kuruluşu niteliğindeki $\mathrm{STK}^{\prime} l \mathrm{ar}^{3}$ tarafindan yürütülen projeler bu konuda verilebilecek en çarpıcı örneklerin başında gelmektedir.

Tedavi edici sağlık hizmetleri yoluyla kurulan etkileşim, tedavi görenler ve yakınları başta olmak üzere toplumun genelinde ve tabi ki yönetimlerde, yardımı gerçekleştiren resmi ve sivil aktörler nezdinde, yardımın kaynağı durumundaki devlete karşı minnet ve güven duygusuyla beraber bir hayranlik ve kabullenmeyi beraberinde getirmektedir. Tedavi edici sağlık hizmetlerinin ihtiyaç sahiplerine doğrudan sunulması yoluyla devletler/hükümetler arasında sağlanan bu olumlu etkileşimin geleneksel diplomasi yöntemlerine nazaran çok daha az maliyetli ve daha etkili olduğu düşünüldüğünde, yumuşak güce dayalı sağlık diplomasisinin önemi ve gerçek bir dış politika aracı olma niteliği ortaya çıkmaktadır.

\subsubsection{Koruyucu ve Önleyici Sağllk Hizmetleri}

Koruyucu ve önleyici sağlık hizmetleri kapsamındaki faaliyetlerin önemli bir kısmı lokal sorunlardan ziyade küresel sağllk sorunlarıyla da ilgili oluğundan, genellikle sağlık alanındaki küresel aktörlerle iş birliği içerisinde yürütülmek durumundadır. Ortaya çıktı̆̆ında belli ve dar bir etki alanında sınırlı kalmayıp kitalar arası yayılan ve hatta dünya genelinde etkili olabilen Ebola, domuz gribi, Zika, SARS, MERS, kuş gribi gibi son yıllarda sıkça gündeme gelen pandemik enfeksiyonlarla ya da AIDS/HIV gibi yaygın sağlık sorunlarıyla mücadelede başarılı olmak için küresel iş birliği zorunlu hale gelmiştir. Bunların yanında özellikle yoksulluğa ve sağlıklı yaşam şartlarından yoksunluğa dayalı yaygın sağlık sorunlarıyla mücadele etmek zorunda kalan toplumlarda/bölgelerde; beslenme sağlığından temiz ve kullanılabilir suya erişime, aşılamadan hastalıklardan korunma konusunda bilinç düzeyinin yükseltilmesine kadar pek çok farklı alanda resmi ve sivil aktörler tarafından önemli çalışmalar yapılmaktadır. Tüm bu çalışmaların yardım yapan tarafların cazibesini ve saygınlığını artırdığı, küresel imajlarını olumlu etkilediği,

3 Türkiye'den de Yeryüzü Doktorları ve İHH başta olmak üzere çok sayıda STK bu konuda önemli çalışmalar yürütmektedir. dolayısıyla da sağlık diplomasisi kapsamında değerlendirilmesi gerektiği söylenebilir.

\subsubsection{Fiziki ve Beşerî Kapasite Geliştirme}

Orta ve uzun vadede sağlık sorunlarının kalıcı çözümüne yönelik gerçekleştirilen bu uygulamaların hedefi, toplumların sağlık düzeylerini yükseltmek, sağlık sorunlarıyla mücadele konusunda dişa bağımlılıklarını azaltmak ve kendi dinamiklerini harekete geçirerek sürdürülebilir bir iyileşme sağlamaktır. $\mathrm{Bu}$ aşamada gerçekleştirilen iyileştirme ve geliştirme faaliyetlerinin; birincisi fiziki kapasite ikincisi beşerî kapasite olmak üzere iki boyutu vardır. Fiziki kapasite geliştirmenin en görünür şekli, yetersiz ve elverişsiz sağlık tesislerinin iyileştirilmesi ya da yenilerinin inşa edilmesidir. Uygun ekipman, tıbbi cihaz, sarf malzemesi ve ilaç gibi sağlık hizmet sunumu için zorunlu ihtiyaçların düzenli tedarikiyle ilgili faaliyetler de bu kapsamda değerlendirilebilir. Beşerî kapasite geliştirmeden anlaşılması gereken ise; uluslararası iş birlikleriyle yürütülen sağlık hizmetlerinin, insan kaynağı bakımından dış yardımlara bağımlı olunmadan gönüllü ya da profesyonel düzeyde sürdürülebilmesi için, yardım alan ülkenin/toplumun içinden bireylerin eğitilerek yetiştirilmesidir. $\mathrm{Bu}$ eğitim programları mevcut imkanlar doğrultusunda; yardım eden ülke okullarına yabancı öğrenci kabulü yoluyla olabileceği gibi, karşılıklı öğrenci ve eğitim görevlisi değişim programlarıyla ya da nihai aşamada yerelde kurulan eğitim kurumlarında, eğitici desteği sağlanarak gerçekleşebilmektedir.

Kapasite geliştirmeye yönelik çalışmalar çok yönlü, maliyetli ve doğası gereği uzun soluklu uygulamalardır. Ancak sağlık diplomasisinden beklenen çok yönlü kazanımların sağlanabilmesi için atılması en doğru ve önemli adımların da bu şekilde kalıcı çözüme hizmet etmesi beklenen uygulamalar olduğu açıktır. Yardım eden tarafın; sınırları, miktarı ve süresi belli olmayan mali ve beşerî kaynak transferine katlanmak zorunda olması ya da yardım alan tarafın; sağlık gibi son derece önemli ve stratejik bir konuda dışa bağımlılığının devam etmesi sürdürülebilir bir ilişki biçimi olmaktan uzaktır. Bu nedenle sağlık alanında uluslararası iş birliğine dayalı ve sağlık diplomasisi niteliğinde kurulan ilişkinin tüm taraflarının fiziki ve beşerî kapasite geliştirme konusunda genellikle istekli olduğu söylenebilir. Sağlık diplomasisi alanında önemli ve başarılı çalışmalara imza atan aktörler olarak; geçtiğimiz yüzyılın ortalarından bu yana Küba ve Çin tarafından (Kickbusch, 2011: 2; Erman, 2016: 82), son yillarda ise Türkiye tarafından -özelikle Somali ve Sudan'da- gerçekleştirilen faaliyetlerin (Battır, 2017: 183) kademeli olarak fiziki ve beşerî kapasite geliştirmeye yönelik uygulamalar içerdiği görülmektedir. Sağlık hizmetlerinin uygun koşullarda yürütülmesi için inşa edilen tesisler ve sağlık eğitimi verilmek üzere kurulan eğitim-araştırma hastaneleri ve okullar karşılıklı anlaşmalarla ve iş birliği içerisinde işletilmek durumundadır. Her türlü maddi kaynak transferinin ötesinde, tecrübe ve bilgi aktarımı yoluyla, bu kurumlar kapasite inşası adına son derece önemli bir fonksiyona sahiptir. $\mathrm{Bu}$ yönde gerçekleştirilen politika ve uygulamaların devletler/hükümetler arasında olumlu ilişkilerin güçlenmesine çok önemli katkılar sağlayacağında şüphe yoktur. 


\subsubsection{Sistem Transferi}

Sağlık diplomasisi çerçevesinde gerçekleştirilecek yardım ve destek uygulamalarının son aşaması, yerel kapasitenin geliştirilmesinin ardından, yardım eden tarafın gelişmiş sağlık sisteminin optimum düzeyde modellenerek yardım alan devlete uyarlanmasına yönelik çalışmaları içermektedir. Sağlık alanında başarılı politikalarıyla uluslararası takdire mazhar olan devletlerin, yardım ettiği devletlere kendi sistemini transfer etmesi de esasen kapasite inşası ve geliştirilmesi süreciyle bir anlamda iç içedir. Kapasiteleri ve yetkinlik düzeyleri farklı devletlerin sağlık sistemlerinin modellenerek birbirine uyarlanması, daha doğrusu yardım alan tarafın sağlık sisteminin yenilenmesi ya da baş̧an kurulması da uzun süreli iş birliklerini zorunlu kılmaktadır. Sağlık profesyonellerince sunulacak hizmetlerden tesis yönetimine ve tedarik süreçlerinden sosyal güvenlik sistemlerine kadar pek çok farklı alanda yapısal dönüşümün söz konusu olduğu bu evrede tarafların karşılıklı bağları güçlenmekte, yardım alan tarafin bağımlılığı farklı bir boyut kazanarak pekişmektedir. Böylece tamamen yumuşak güce dayalı olan sağlık diplomasisi sayesinde, yardım eden tarafin uluslararası kamuoyunda prestiji artmakta ve etkileşim alanlarında güçlü bir meşruiyet zemini elde etmesinin önü açılmaktadır.

\section{Sonuc}

Uluslararası ilişkilerin belirleyici unsuru her dönemde tartışmasız "güçc, bu ilişkilerin en önemli aracı da diplomasi olmuştur. Güç ve diplomasi arasında, nitel ve nicel kapasitenin uluslararası politika uygulamalarındaki etkinlik düzeyini belirleme bakımından doğru orantılı bir ilişski mevcuttur. Yani birinin varlık düzeyi yükseldiğinde diğerinin etkinliği artmakta, düştüğünde ise azalmaktadır. Soğuk Savaş'ın sona ermesi ve küreselleşme olarak kavramsallaşan sürecin hayata dair her alanda çok yönlü etkileriyle daha görünür hale gelmesiyle birlikte uluslararası politika aktörleri arasındaki ilişkilerin, toplumlar arası etkileşimin ve bunların yanında iç ve dış politika gündemlerine dair algıların önemli ölçüde değiştiği, yeni bazı kavram ve olguların gündeme geldiği görülmektedir. Küreselleşme çağında uluslararası sistemde güç olgusu artık, niceliğe dayalı geleneksel algılanışından farklı, çok daha geniş bir anlamı içermekte ve devletlerin güç tercihleri de bu yeni duruma göre şekillenmektedir. Uluslararası politikada devlet düzeyinde bir aktörün, ekonomik ve askeri potansiyelini yaptırım aracı olarak kullanmak suretiyle, diğer aktörlerin tercih ve davranışlarında değişiklik yapma veya üzerlerinde nüfuz elde etme kabiliyetiyle ilgili olan sert güç artık yegâne ilişsi biçimi olmaktan çıkmıştır. Bunun yerine devletlerin; sahip olduğu maddi ve manevi değerlerle cazibe oluşturarak, özendirerek ve yanına çekerek, başka devletleri kendi hedeflerine uygun davranmaya yönlendirmesiyle ilgili olan yumuşak güç, daha az maliyetli ve uzun dönemde daha etkili bir "yeni" etkileșim modeli olarak uluslararası politika gündeminde kendisine yer bulmaya başlamıştır.

Uluslararası politikaya dair kavramlar ve olgular değişse de güç ve diplomasi arasındaki ilişkinin varlığı ve yönü bundan pek etkilenmemektedir. Bu ilişkiye bağlı olarak; gücün ekonomik ya da askeri unsurlardan ziyade bilime/teknolojiye dayanır hale gelmesi ve bunun yanında siyasi ve sosyal dinamiklerle şekillenmesi yeni diplomasi süreçlerini, diplomasi pratiklerindeki yeni gelişmeler de gücün kavramsal çerçevesini ve kullanım tercihlerini etkilemektedir. Gücün ve güç tercihlerinin değişip dönüştüğü, sert güç yerine yumuşak gücün öne çıktığı bu süreçte, diplomasi kavramının da buna uyumlu olarak yeni boyutlar kazandığı, çoğu birbiriyle ilişkili yeni diplomasi uygulamalarının gündeme geldiği görülmektedir. Son yıllarda bilinirlik düzeyi giderek yükselen ve uluslararası ilişkiler disiplini içerisinde yer edinen; kamu diplomasisi, kültürel diplomasi, insani diplomasi gibi yeni etkileşim biçimlerinden biri de sağlık diplomasisidir.

Sağlık diplomasisi, işleyişi, uygulama süreçleri, hedefleri, araçları, etkileşim düzeyleri ve aktörleri bakımından, geleneksel anlamda diplomatlar eliyle yürütülen formel dış politika pratiklerinden farklı bir yapıya sahiptir. Sağlık diplomasisinin resmi aktörleri devletler ve devletlerden müteşekkil uluslararası kuruluşlar/organizasyonlar, sivil aktörleri ise STK'lar ve özel sektör sağlık girişimleridir. Devletlerin aktörlüğünden kasit, devlet yapısına dahil olan ve bünyesinde bulunan sağlık profesyonelleriyle uluslararası düzeyde faaliyetler gerçekleştiren tüm resmi kurum ve kuruluşların aktörlüğüdür. Sözü edilen resmi ve sivil aktörler tarafından kendi ülkeleri dışında gerçekleştirilen ve sağlı diplomasisi kapsamında değerlendirilen faaliyetler, geleneksel diş politika uygulamalarının dışında kalan ve esasen formel diplomasiyi tamamlayıcı nitelikte alternatif etkileşim kanallarıdır.

Küreselleşmeyle birlikte insanlar, toplumlar ve devletler arasında her türlü irtibatlanmanın sıra dışı boyutlara ulaştı̆g 1 günümüz uluslararası sisteminde, dünyanın herhangi bir bölgesinde ortaya çıan ve zaman zaman insani kriz boyutuna ulaşan sağlık sorunları, çok kısa bir süre içerisinde -coğrafi olarak en uzak noktada olsa biledünyanın herhangi bir ülkesini/bölgesini, doğrudan ya da dolaylı olarak olumsuz etkileyebilmektedir. Sağlık diplomasisi bu anlamda; küreselleşmenin yol açtı̆̆ sorunların, yine küreselleşmenin getirdiği imkanlarla ve uluslararası iş birlikleri yoluyla çözülmesine yönelik faaliyetler bütünü olarak görülebilir.Bu yönü düşünüldüğünde, söz konusu olumsuzlukların yaşandığ 1 bölgelerde sağlık sorunları henüz büyümeden atılan ön alıcı adımların, sadece soruna maruz kalan insanlara/toplumlara sağlayacağı fayda açısından değil, çözüme katkı verme durumundaki aktörlerin -ve aslında tüm insanlığıngüvenliği açısından da stratejik ve rasyonel bir davranış olduğunu kabul etmek gerekir.

Sağlık diplomasisi niteliğindeki faaliyet ve uygulamalar genellikle hükümetlerin karşılıklı iş birlikleri çerçevesinde gerçekleştirilmektedir. Bunun dışında hükümetler/devletler küresel sağlık aktörleri durumundaki uluslararası kuruluşlarla birlikte hareket ederek ya da STK'lar ve özel sektör girişimcileri gibi sivil aktörleri destekleyerek de sağlık diplomasisi yürütebilmektedir. Acil yardım ve arama kurtarma faaliyetlerinden tedavi edici ve koruyucu sağlık hizmetlerine, fiziki ve beşerî kapasite inşasından sağllk sistemi modellemesine kadar çok farklı düzeylerde uygulamalarla ortaya konulan sağlık diplomasisi, genelde gelişmiş ülkelerden az gelişmiş ya da olağanüstü olumsuz şartlara maruz kalmış ülkelere/bölgelere yönelen yardım ve destek programları şeklinde gerçekleşmektedir. Uygulayıcıların -maddi ve beşerî- belli maliyetlere katlanmasını gerektiren bu tür program ve faaliyetlerin kısa vadede en önemli getirisi uluslararası toplum nazarında 
ülkelere kazandırdığı prestijdir. Ancak bu ülkelerin orta ve uzun vadede daha büyük kazanımı; -küresel sağlık sorunlarının çözümüne katkıları ölçüsünde- uluslararası aktörler içerisinde ayrıcalıklı bir konum elde ederek sistem içerisindeki etkinliklerinin artması ve uluslararası toplum nezdinde meşruiyet düzeylerinin yükselmesi şeklinde gerçekleşecektir.

\section{Kaynakça}

Adams, V., Novotny, Thomas E.,\& Leslie, H. (2008). Global Health Diplomacy.Medical Anthropology, 27(4): 315-323.

Arı, T. (2013). Uluslararası İlişkiler ve Dış Politika. 10. Bask1, Bursa: MKM Yayıncilık.

Ateş, D. (2012). Uluslararası Örgütler: Devletlerin Örgütlenme Mantı̆̆g. Bursa: Dora Yayıncılık.

Ateş, D. (2013). Uluslararası Politika. Bursa: Dora Yayıncilik.

Battır, O. (2017). Insani Diplomasi. Konya: Çizgi Kitabevi.

Baylis, J. \& Smith, S. (2005). The Globalization of World Politics, An Introduction to International Studies. New York: Oxford University Press.

Bourne, P. (1978). A Partnership for International Health Care.Public Health Reports 93(2):114-23.

Çavuş, T. (2012). Dış Politikada Yumuşak Güç Kavramı ve Türkiye'nin Yumuşak Güç Kullanımı.Kahramanmaraş Sütçü Imam Üniversitesi Íktisadi ve İdari Bilimler Dergisi, 2: 23-37.

Dağ, Ahmet E. (2004). Uluslararası İlişkiler ve Diplomasi Sözlüğ̈̈. İstanbul: Anka Yayınları.

Dahl, R. (1957). The Concept of Power.Behavioral Science, 2 (3): 201-215.

Drager, N. \& Fidler, D. (2007). Foreign Policy, Trade and Health: At the Cutting Edge of Global Health Diplomacy.Bulletin of the World Health Organization, $85(3): 161-244$.

Erman, K. (2016). Sessiz ve Etkili: Küba'nın T1p Diplomasisi. Uluslararası İlişkiler, 48(12): 77-94.

Fauci, Anthony S. (2007). The Expanding Global Health Agenda: A Welcome Development.Natura Medicine, 13(10): 1169-1171.

Gönel, A. (1998). Önde Gelen STK'lar Araştırma Raporu. İstanbul: Türkiye Ekonomik ve Toplumsal Tarih Vakfı Yayınları.

Gönlübol, M. (1993). Uluslararası Politika.Ankara: Attila Kitabevi.

Haştemoğlu, G. (2004). Türkiye'de STK'lar Alanında Hukuksal Gelişim ve AB Sürecinde STK'lar.İçinde: N.
Boztekin (Ed.),AB Uyum Süreci ve STK'lar. İstanbul: Türkiye Ekonomik ve Toplumsal Tarih Vakfi, 33-54.

Health Diplomats. (2009). Health Diplomacy.(Erişim: 05.02.2019),http://www.healthdiplomats.com/index.php ?page $=31$ health_overview

Holsti, K. J. (1964). The Concept of Power in the Study of International Relations.Background, 7(4): 179-194.

Kalın, İ. (2011). Soft Power and Public Diplomacy In Turkey.Perceptions, 16(3), 5-24.

Katz R., Kornblet S., Arnold G., Lief E., \&Fischer J. E. (2011). Defining Health Diplomacy: Changing Demands in the Era Of Globalization.The Milbank Quarterly, 89(3): 503-523.

Kickbusch, I., T. Novotny, N. Drager, G. Silberschmidt, \& S. Alcazar. (2007). Global Health Diplomacy: Training across Disciplines.Bulletin of the World Health Organization,85(12): 971-973.

Kickbusch, I. (2011). Global Health Diplomacy: How Foreign Policy Can İnfluence Health.BMJ,Global Health Programme, Graduate Institute of International Studies, 1211(342):1-3.

Kürkçüoğlu, Ö. (2005). Dış Politika Nedir? Türkiye'deki Dünü ve Bugünü.Ankara Üniversitesi Siyasal Bilgiler Fakültesi Dergisi, 35 (1): 309-335.

Morgenthau, Hans J. (1948). Politics Among Nations. New York: Alfred A. Knopf.

Nye, Joseph S. (1990). Soft Power.Foreign Policy, 80: $153-$ 171.

Nye, Joseph S. (2011). The Future of Power. New York: Public Affairs.

Oral, Burcu G. (2014). Sağlık Hizmetlerinin Küresel Kamusal Mal Olarak Değerlendirilmesi: Uluslararası Örgütler.Finans Politik \& Ekonomik Yorumlar, 51(588): 79-95.

Sönmezoğlu, F. (2005). Uluslararası Politika ve Dış Politika Analizi. İstanbul: Filiz Kitabevi.

Waltz, K. (1990). Realist Thought and Neorealist Theory.Journal of International Affairs, 44(1): 21-37.

Wenger, Andreas (2001). The Internet and the Changing Face of International Relations and Security.Informaiton \&Security, 7: 5-11.

WHO (World Health Organization), (t.y./tarih yok). Global Health Diplomacy, (Erişim:01.02.2019), https://www.who.int/trade/diplomacy/en/

Yılmaz, E. (2007). Uyuşmazlık Çözümünde Toplumlar Arası Diplomasi Yöntemi.Yönetim ve Ekonomi $\begin{array}{llll}\text { Araştırmaları Dergisi, } & 5 & \text { (8): } & \text { 42-47. }\end{array}$ 
